\title{
THE RELATIONS OF THE STATION ENTOMOLOGIST TO HIS ENVIRONMENT
}

F. I. Washburn, Entomologist, State Experiment Station, Cininersity of Minnesote, Minneapolis.

\section{The Economic Entomologist and General Conditions Surrounding} his Work:

At the very beginning it must be said that the Economic Entomologist occupies an anomalous position among professional workers. $\mathrm{He}$ is not a scientist in the strictest sense of the term, nor is he a systematist, and he certainly is not a farmer, whom it is his duty to serve, but, partaking somewhat of each of these classes, he is looked at askance by all three. Reviving certain ancient terms, we might say the "eggslicers" of Johns Hopkins have no use for him, the "species makers" at Washington would hardly receive him with open arms, and the farmer, as you know, looks with suspicion upon anything not sufficiently connected with the soil to warrant his stamp of approval. Wo find the entomologist, then, a man "betwixt and between." His cousin, working on entomology in an institution not given over to economic questions, can choose the problem to which he feels especially ealled, while the station entomologist has to be ever ready to solve riddles, not of his own seeking always, but questions of all kinds which are thrust upon him, frequently quite unexpectedly, and in such numbers that they cannot be solved in a life time.

On the other hand, the work of the scientist is not, by any means, appreciated in the practical world of today among such a large class as is the work of that one who makes use of a few facts determined by the former, applying them in a way advantageous to the public.

The successful economic entomologist of today is essentially a practical man, keenly observant, with a knowledge of botany and general agriculture, a judge of human nature, a good mixer, a good speaker, and, ferhaps we should add, a good politician, in the cleanest interpretation of the term. He is, withal, systematic in his work, a careful note taker, just and generous to his fellow workers.

Finally, these qualifications must rest upon a good foundation in the way of preparation for the work. He publishes what he thinks he knows, sometimes pullishing too quickly, be it said, for he frequently has cause to change his views after his earlier conception has been frozen in cold type. He makes mistakes,--Heaven protect us from the man that does not! With all the printed matter on entomology coming to his desk, he may fall into the habit of skimming superficially 
over literature bearing upon his work, and may, and sometimes does, draw incorrect conclusions from his reading. The habit of hasty reading is happily overcome, however, by the use of subject index cards, with which we are all familiar.

Points upon which many entomologists (as well as other station workers, be it said) may be criticised are plagiarism, non-acknowledgment of facts or illustrations obtained from other entomologists, the taking away of records of experiments, and making use of same after leaving an institution; borrowing specimens for a period of ninetynine years or more; deliberately attempting to obtain an offer from some other institution in order to make use of it in getting a raise of salary in the station in which he is already employed, and other misdeeds of a more or less glaring nature.

Perhaps one of the worst failings of the average entomologist is to accept without proof the statements or conclusions of ils fellow workers, and errors are thus transmitted sometimes from one generation to anothcr, until some one more thoughtful than his contemporaries or predecessors, by his own work discloses the error of a certain statement. Unfortunately there are among us few entomologists bold enough to publicly criticise their own publications, when they have discovercd a mistake, though an early rectification might do a world of good. Duplication of work, then, would seem desirable both as a check, and to put an end to the transmission of erroneous statements.

We are all, I think, learning that it is unwise to make predictions as to insect injury. As you may remember, it was predicted that the Cotton Boll Weevil would never advance to the point it has reached, yet, in spite of this, and similar warnings, I am today repeatedly predicting in Minnesota that no grain aphis will, on account of our climate, which is practically as favorable to aphid parasites as to the aphids themselves, cause any serious injury in our fields.

The importance of constant watchfulness over our own work and our own words cannot be overestimated,-a mistake before the public is costly,-we lose the confidence of our constituents; as President Vincent of our own University has aptly said: "The discomfiture of the expert is joy to the average citizen!"

One great disadvantage we labor under lies in the fact that we do not hear all the criticism which may be given our work. We are applied to for relief, we give that relief to the best of our ability, and in eight cases out of ten that is the last we hear of it. Our constituent may have failed to get good results, either through his own negligence or carelessness, or through our not understanding all the conditions surrounding his problem. He may be heaping maledictions upon us 
in his own mind, of which maledictions we are profoundly unconscious. We work largely, be it said, under the ban of the "silence of the critical." It is a far cry from economic entomology to poctry, yet I am led to cularge upon this by quoting a few lines from a poem by O. W. Firkins of the Lniversity of Minnesota, not yet published. This silence is like

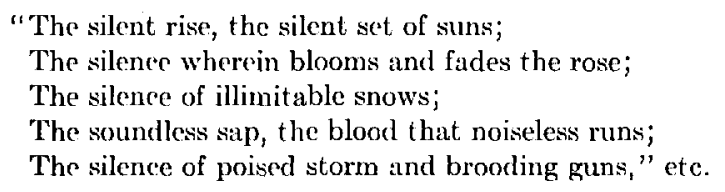

I have believed in the past most thoroughly in the entomologist, and all scientists in fact, or men of any profession, having hobbies quite distinet from their work. I have believed, and still believe, that any man in a profession who has a lively interest in some recreative work or play brings so much more to his specialty, yet I see danger, as we advance toward middle life and beyond, and our ambition in our profession becomes possibly a little less keen, that one may give too much attention to a hobby, and too little to his specialty, in other words, the hobby and the specialty may change places. This is, most certainly, to be guarded against.

2. Relations of the Economic Entomologist to the Farmer:

We can perhaps all unite in saying: "God bless the insect!" It creates the entomologist, and makes for diversified farming; it turns wheat growers, corn growers, cotton growers and others into genuine farmers, and our relation to the latter is perhaps the most important of all, since it was to promote the cause of agriculture that our office was created.

It is a pleasure to note that while some years ago any professor was looked upon as unpractical, a bookworm, and a dreamer, the professor of today is a specialist, he is appealed to frequently by the public, and despite the criticism previously alluded to in this address, this fact, in connection with our work, is encouraging, and it is a pleasure to realize that it is appreciated.

The inducing farmers to accept results, however, and teaching them how to apply an effective remedy for certain destructive pests is a difficult and very important part of our work, more difficult, perhaps, than finding the remedy itself. It represents almost one half of the problem; this need of constant reiteration of methods which you may have published and spread broadcast in the past, feeling secure in the belief that every one knew and practiced them. We frequently awake to the realization that a large portion of our farmers are ignorant of 
the simplest truths published in the earlier part of our state work. I think we are frequently not explicit enough with farmers; they are suspicious of new remedies, slow to adopt them, and some still have the attitude of holding the professor's results in contempt. Here is where the work of the Agricultural Extension Division can be and is effective.

The value of a personal interview also cannot be overestimated; personal contact counts for much more than letters, which latter, even though carefully worded, are sometimes misleading, and may possibly convey an impression entirely at variance with the thought of the entomologist. This impression might be easily righted in a conversation with a farmer, or in a general talk before a body of tarmers. Then, too, a trip to see a farmer, or a body of men interested in agriculture, is to them a compliment and a source of gratification. It cannot be denied that our constituents are hard to win over to our views. As a rule orchardists are progressive and glad to make use of the entomologist's results; or, is it that they realize a lower price is paid for fruit exhibiting any blemish caused by an insect? Many lumber men, possibly, are quick to take advantage of facts disclosed by our work, but we venture to say that not a very large proportion of the lattcr follow the scientific methods suggested by Hopkins, intended to control the devastations caused by various insects. Some market gardeners are alive to the value of modern methods; some invent good methods of control themselves, but the general farmer, as stated above, is hard to win over; it is with the younger generation, the coming farmers, that our work is the most effective. The imprortance of personal contact with the farmer is so great that if the chief himself cannot give time to it, we believe there should be at all times during the growing season, men in the field who represent the chief. These men should be carefully chosen. They should be efficient, honest, well grounded in their work, and last, but not least, mature, and good mixers. Do not send out boy assistants among your constituents.

Some farmers, particularly the foreign farmers, are suspicious and fatalistic, both of which qualifications are obstacles to our work. They are also somctimes suspicious of friendly overtures, or, on the other hand, expect the state to go to all the expense and trouble of freeing their ficlds of vermin.

Manifestly the same general axioms above cited, would apply to our relations with stock raisers, housekeepers, nurserymen and others, though the inspection of domestic and imported nursery stock plays such a prominent part in our work that it calls for and will receive, in this address, a chapter by itself. 
3. The Relation of the Entomologist to the Director of the Station, to Other Administrative Officers, and to his Fellow Station Workers:

While there is a marked difference of policy in administration in different stations, and while some of the younger institutions have had to go and are going through a period of political upheaval, very disastrous to good work, most of us, I assume, are fortunate in being associated with directors of broad views, honest in the treatment of their staff, and, in many instances, we find a bond of friendship often, which, far from being the cause of any partiality, goes a long way toward advancing harmonious and productive work. Due deference, of course, is to be paid the director and his position in his official capacity. He frequently acts as an advisor without dictating, or in any way hampering the projects of his entomologist.

Where the station is connected with the state university, as it is in many of our states, official communications from the entomologist to the president and board of regents should, and generally do, go through the director to the chief executive. The business relations, therefore, of the entomologist, are entirely with the former, and it is unwise, as some of the younger and more hasty, and a few of the older entomologists may have discovered, to attempt to go around the director. Any direct clash, or an appeal to higher authorities is apt to result disastrously. This is as it should be, even though the entomologist may have right on his side, for any other result, in nine cases out of ten, would be disastrous to the discipline of the institution. Happy the entomologist where the station staff, aware of the fact that each one is working for the common good, and not ambitious to advance his own reputation at the expense of community interests, meet in council where projects of various kinds are discussed in a friendly and harmonious way.

I believe, since the faculty of the college, or the working staff of the station, is the bone and sinew of the institution, that there should not be so great a discrepancy between the salary of the directors or deans and the members of the working force as prevails in some of our institutions. Something nearer an equal footing goes far toward promoting the best work.

It is to be deplored that, in comparison with other divisions, the division of entomology is frequently allowed but small financial assistance for its work, rather lowering its importance in the eyes of the public and other station departments. While horticulture, agriculture, animal husbandry, etc., get, as a rule, liberal appropriations, the entomological appropriations are apt to be out of all proportion to the important relation the work bears to these leading subjects. 
It is unfortunate ${ }_{i}$ too, and in a measure accounting for the condition just cited, that from the public viewpoint economic entomology is not conspicuously constructive. People see the gratifying results produced in agronomy, horticulture, animal husbandry, and agriculture, and usually regard entomological work as of minor importance, a side issue, possibly, a little of which, a very little, is necessary to secure best results in the other branches of agricultural work.

A source of annoyance to the entomologist of a station, where the funds of his division are controlled by the university authorities, is frequently found in the relations to the comptroller or purchasing agent of the university. The ruling that requires all supplies to be bought by the purchasing agent is a "penny wise and pound foolish" policy, where the custom prevails of this officer accepting the lowest bid for material for scientific work. This results, at times, in the institution obtaining what the entomologist or other worker cannot use, and is an actual money loss to the institution. I have known, in the past, of a purchasing agent sometimes changing one's order, through a mistaken sense of economy, the agent having apparently thought something else would do as well. The loss and disappointment caused in this way could be prevented if the professor in charge were allowed to order his goods directly. While these mistakes and vexatious delays are to be deplored, we should respect the necessity which demands that an institution should be businesslike, and expenditures kept within its income.

Loyalty toward an institution on the part of its employees is, of course, an absolute necessity, but we must not overlook the fact that loyalty on the part of an institution toward its employees is equally necessary. An entomologist employed by a station on a given salary to do a certain stipulated amount of work, should not be compelled to add to his work and responsibility without a perfect understanding and an agreement to that effect between the director of the station and himself. This principle is undoubtedly recognized by most directors. When an institution, through its executive head, has adopted the policy of saying to members of its working force (and it is to be regretted that there are such institutions): "Show us a larger offer from another institution, and we will consider raising your salary," a deliberate invitation is extended to a worker to treat with other institutions with this object in view. Under these trying and unsanctified conditions I believe an entomologist is justified in sceking relicf. The policy smacks too much of business methods and too little of professional ethics and college courtesy.

Co-operation in some large problem upon the part of members of a station staff does much toward doing away with selfish atms and 
aspirations on the part of the individual. Where station workers intimately concerned with the work, take up the subject of corn, for example, or clover, or other crop, treating the problem in all its aspects, the force is working more as a unit, and we get more of a co-operative feeling than in any other way.

\section{The Entomologist's Relations to his Employees:}

Honesty, loyalty, ability and generosity are the prime requisites on the purt of assistants in the entomological department; are they not also the requisites to be looked for in the chief entomologist in his relations to his cmployees? Should he not give all due acknowledgment to his assistants, if necessary erring a little on the side of generosity in this connection, to create good feeling and confidence?

The question of granting credit to assistants has been well and frequently discussed in this Association, and the concensus of opinion appears to be in favor of giving all eredit for originality on the part of an assistant where he has done a piece of work in question entirely by himself, with little or no direction from the head. Even when such help has been given, some entomologists are altruistic enough to waive their claims in the work and give all credit to an assistant.

The general rule above mentioned, seemingly followed by all members, appears excellent, yet there are at times objections to the plan. Human nature is not always strong, and ambition on the part of an assistant to get credit for a piece of work is sometimes so great as to blind him to the advantage accruing from consultation. Some possibly will avoid consultation with the chief for that reason, and thercby the best results are not only not secured, but an entire season of work may be wasted. Frequently two heads are better than one in an entomological problem, and the assistant should be generous enough toward the work to admit that. One station worker known to me, chief of his division,-- and there are probably others,- follows this method with seeming success; he will materially help an assistant in a project undertaken by the latter, yet allowing the assistant to have full credit. In return he expects his assistants to do the same in the projects that belong distinctly to him.

The young entomologist, for a few years, should be absorbent rather than exhalent. It would be well for him to follow the old adage to "say nothing and saw wood" for a while, and scek to bind his friends and employers to him with hooks of steel. One point, especially, he should bear in mind in connecting himself with an institution; namely, that all notes, records of work, photos, drawings, etc., made during working hours, are distinctly the property of the institution. This also applies to the notes (which must be something more than mental 
notes) of the chief of the division, and covers the case where a temporary assistant takes away with him a duplicate copy of a report of his work, which he may, or may not use in another institution, or in some method in no way connected with the institution employing him when the records were made.

While on the subject of employees, let me say we should, I believe, adopt the policy of spending more money on men of high efficiency, rather than on apparatus or publications. Able men in economic entomology are so rare that only the institutions financially fortunate, and following a generous policy can hold them.

\section{The Relations of an Economic Entomologist to Students:}

Not all entomologists teach; on the other hand some have more teaching, much more, than is compatible with research work, and again, we find a favored few with just enough teaching to vary their other work. I believe, other things being equal, that the earnest investigator makes the best instructor. A platform speaker, one who is constantly addressing the public, is rarely a good teacher, since he acquires a looseness of expression, and a certain superficiality of thought which affects his teaching relations with students.

It is evident that there is not enough teaching of economic entomology, at least (possibly because the subject is looked upon by the authorities as a side issue); it is not taken seriously enough in many of our institutions, to enable us to turn out enough sufficiently competent men each year to fill positions offering emoluments of from $\$ 1000$ to $\$ 2500$ yearly. I am speaking now largely from my own experience. Every year we have demands upon our institution in this line which we cannot comply with, and it is to be hoped that you will all use your influence where needed, to strengthen this hitherto weak point in economic entomology.

\section{The Relations of an Economic Entomologist to Agricultural E'xtension:}

Agricultural extension has, in some of our institutions, the rank of a division, on the same basis as other divisions, and it has for its duties the placing before farmers in a popular way the results obtained by other divisions, as well as taking charge of meetings, such as, in some states, Farmers' Institutes, and the like, the holding of short courses for farmers, demonstrations in the field, demonstrations at fairs, exhibits, etc. Such a division in the station, and Agricultural College is of great value, relieving other divisions of much of the routine work otherwise demanded of them. I am now speaking of the only one with which I am familiar, namely, the Agricultural Extension Division in the Agricultural Department of the University of Minnesota. In the case of this division its enormous mailing list enables 
it to get literature to a vast number of farmers; this literature consisting of extension bulletins, Farmers' Library and similar matter, as well as press sheets to state papers and the press at large.

The good accomplished by such work is great, though not always ummixed with disadvantages, for since the extension division staff is not made up altogether of specialists, and one man frequently has to talk upon a number of subjects in different fields, an entomologist is somewhat surprised, to say the least, at incorrect or half complete information in his line, emanating from such a division, and inasmuch as the entomological division gets blame or praise for anything in the insect line coming from the experiment station, I believe all questions relative to insects, received by the agricultural extension division should be referred to him, and that, in general, the work along different agricultural lines, as representing the different divisions, should be directed by the specialists on the station staff, whose work it concerns. This was, as stated above, evidently the original intention in establishing the division, and a plan which should be followed in any experiment station or agricultural college proposing this feature.

In November of the current year it was my privilege to hear President Butterfield discuss Agricultural Extension at the Columbus meeting. It seems that thirty-two states have agricultural extension in some form. It further appears to have been the idea of the committee that the extension division should be thoroughly co-operative when it is a part of an agricultural college, and that it should not act independently of other divisions. Technical subjects presented by the extension division should either be handled by station men directly engaged in such questions, or by extension men acting under the supervision of the station specialists. Otherwise we are apt to find the station men and agricultural college professors advancing ideas to students quite at variance with those promulgated over the state by the extension force. It would scem, then, that unless extension divisions feel the importance of this co-operation, and act accordingly, they fail in their purpose. It has further been suggested that not only should the extension division help the farmers along the lines indicated above, but that it is equally its duty to bring to the notice of station workers, agricultural conditions prevailing in different parts of the state which call for special attention.

7. The Relations of an Economic Entomologist to his Fellow Entomologists, and the Relations of this Association to the Public:

Surely these yearly meetings are of inestimable value, not only in affording each entomologist an opportunity to bring back to his state 
new views of advantage to the citizens of that state, but also as an encouragement and stimulus in the way of our ideals and aspirations, the mere being together as a unit adds to our self-respect, and the strength of our cause. Like the traditional bundle of sticks; which the old man bade his sons get together, we present together an impregnable cohort, though singly, in our own bailiwicks, each one of us has frequently to bend to the storm, and has felt from time to time, perhaps, not unlike a bruised and broken reed.

Though having interests in common, each of us is confronted by conditions somewhat different from those of his fellows. Each of us takes on, if you please, the "color" of his locality, and since cifferent localities call for different lines of work, when we think of a certain individual his special line of work is suggested by his name. Finley's word "ergocentric" applies here, by which he would designate the method of regarding an individual in the light of his occupation or job, and measuring his efficiency in ergons. We expect an entirely different class of papers from men of different sections of the country; the mention of one man's name suggests grain pests; another, insecticides; another, boll weevil; others fruit insects, etc. Since we used the word "color" above, let us carry the fanciful illustration farther, and say that each one of us may represent a colored patch in the makeup of Joseph's coat, but collectively, we represent a pretty good cont, and unlike the woven garment of Biblical times, we will add materially to our strength and beauty as time goes on.

I believe, if any criticism is to be made upon this Association as a body, it is that we have in the past lacked organization, and have not realized the value of co-operation. This lack is being overcome, and Sanderson's motion that we keep in touch with each other's work for the purpose of co-operation, was a movement in the right direction. Apropos of this motion, I note that Dr. Smith, as early as 1895, in his presidential address, mentioned our needs along this line.

The present year's request, in connection with what we may well call the Sanderson-Headlee list, appears to call for too elaborate information. Few of us are willing to take the time to send to headquarters all of the data asked for. In our opinion it is sufficient to name the problem, and let each man determine how much information he cares to make public, and how far he cares to go in co-operating and discussing methods with some other man who has a similar problem. It might be said in passing that this publication of our projects in no way conflicts with the rulings in the office of Experiment Stations as regards Adams Fund projects. Dr. True, in deference to wishes expressed or unexpressed, is not inclined to make public a list of Adams Fund projects, simply in order not to offend any one desiring to keep 
his project to himself, but he sees no possible objection to any entomologist so desiring, to make his Adams Fund project a matter of public information.

One word as regards our programme: That we should have more time has been our constant plea. I believe, further, that we would save time if the presidential address were made, and the first business session held in the evening.

I would suggest avoiding long technical papers with tables, all of which can be better read than listened to, and, I believe it has been decided to read by title only, except in symposia, those papers whose authors are not present. After all it is the personality of the man we seek and enjoy. We can read his paper if we wish to in our Journal. We are fortunate in having this publication, and it certainly deserves the support of each and every one of us.

In looking over the list of projects of the present year, compiled by Chairman Headlee, I note activity along important lines, and believe (in spite of some minor criticism when the plan was suggested) that this work will do much to promote co-operation and progress. I have already given the report of the committee on the Entomological Employment Bureau. The need of some such action upon our part was shown at our last meeting, and has been apparent, I believe, for many years.

Regarding legislative matters, you all know the conditions under which we labor. I believe our legislative committce should be larger than at present-a committee of five or six can put up a bolder front before a Congressional committee than a committee of three, and it frequently happens that of the three only two can be at Washington at the proper time. A discussion of the so-called "Howard Bill" belongs more particularly to the Association of Horticultural Inspectors rather than to this Association, yet the Chair is ready and willing to put to vote any motion made along this line.

There is a bill pending before Congress, known as the Page Bill, which, I believe, materially affects us as station workers, and which appears to meet, according to utterances at the Columbus meeting, with decided objections upon the part of many station representatives. Under the provisions of this act a state would be given a large amount of money for extension work upon condition that the legislature appropriate an equal sum. Some states in which agricultural colleges are already very liberally provided for would benefit by this bill, but it would appear that, in states where the institutions are not so generously cared for, this bill, if it became a law, would work a hardship. It would be, in such states, very difficult for the station, and consequently, for the entomological department or division, to secure for 
general work a decent allowance of state funds, since it would result in such a drain upon the state treasury to meet the demarids of the Page Bill conditions, that some of the agricultural colleges and experiment stations would get but little state money for departments other than the extension division. It would appear then, if we were to take any active part as a body, in federal legislation, that this is a matter for our careful consideration.

The executive committee has made a most determined effort to influence the directors of the various stations to pay the way of their entomologists to these annual meetings. Your President with the knowledge and approval of the other members of the Executive Committee, met the Committee of the American Association of Agricultural Colleges and Experiment Stations on Station Policy and Organization at the Columbus meeting in November. At their hands the project received generous consideration, and we can congratulate ourselves upon the fact that we have made a step forward toward the desired goal. The text of the resolution as passed by the Association is as follows:

"At the request of one of the societies, with which members of the Station's Staffs would naturally be associated, the question of members of the staff attending the meetings of the Scientific Societies was discussed. Your committee believes that the leading members of the Staff should, for their own sakes, so far as they are able, attend the sessions of at least one such Society annually. It also believes that the Station administration should be alive to the fact that there are frequently meetings and conventions which the best interests of the Stations demand that it be represented. In such cases, the proper official should be sent as the Station's representative and at its expense."

The details of the working out of this policy belong to administrative bodies in connection with each station, and, therefore, it is left to each station to arrange. In considering this matter the committee on station organization and policy took the ground, naturally, that this should apply to all divisions; that it should not be regarded for a moment as a charity on the part of the station toward one of its workers, but rather as an advantage to the station to have its men at the meetings, thereby helping it to keep in touch with the most modern methods. Of course, the Association of Agricultural Colleges and Experiment Stations cannot dictate to the boards of regents, or boards of trustees, but, I believe that directors as a whole are trying to look upon this matter favorably, and it is for you as entomologists to present your claims to your various stations, and to use your influence in this direction as far as possible, It might be wise, perhaps, to ask for a general traveling fund as a part of your budget, of such a size as to enable you 
to use some of it, when the proper time comes, to be present at these meetings.

While attending the above meeting I was struck with the value to the station entomologist of many of the papers and discussions, and I am quite of the opinion, an opinion shared by a number of the members of this association, that we would do well to affiliate with the American Association of Agricultural Colleges and Experiment Stations, not necessarily cutting off from the American Association for the Advancement of Science, but perhaps holding alternate meetings with each one of the aforesaid associations. An entomologist of the station is frequently brought into such intimate relations with the policy of administration of station affairs and agricultural college affairs that such an affiliation would seem to be most advantageous. Further, it is extremely probable that gradually associations and societies treating on subjects allied to ours will meet at the same time as the above named association, so that if 'our sessions were held prior, or after the sessions of the other societies, we would have an opportunity to attend the sessions of the societies referred to. I believe that under these conditions it would not be so difficult for station entomologists to have their traveling expenses to the meetings taken care of. I shall be very glad to leave this matter with you for your discussion and vote. Such affiliation may be considered from two standpoints; a personal standpoint, and the standpoint of the public. One worker has told me that he would prefer to be affiliated with the American Association for the Advancement of Science, because he gets more of a cultural uplift, as he expresses it, from association with the more technical and scientific workers. This thought may have occurred to others of us. On the other hand, the needs of our station work should be considered. How are these needs to be best supplied?

A few states, sad to relate, at least we know of one, have state laws making it impossible for a station to pay the way of any of its staff to mectings outside of the state. It is unfortunate and evidently arises from the thought on the part of the legislature that such trips are for pleasure, rather than for business. Entomologists should do all they can to convince farmers in the various states that these are not junketing trips. A director in a state so hampered would be acting along progressive lines if he sought to have such narrow-minded legislation repcaled.

Wc are pleased to note the presence, as an active factor in our work, of the federal insceticide law, and to add that some of our'states, Minnesota at least, have also state laws in no way conflicting with the foderal law. These laws should serve to protect our farmers and orchardists from impositions. 
Our relations to the Federal Bureau are so close that a word in passing may not be out of place. It is undoubtedly the policy of the Bureau, when sending its field workers into any state, either to co-operate with the station entomologist of such state, or have an understanding with him along this line. This is purely a matter of professional courtesy, and I believe such process is invariably followed by Dr. Howard.

It is a deplorable fact that the Department of Agriculture will not assist its men pecuniarily in attending these meetings, from which they would naturally reap so much profit. This results ir. a marked depletion in attendance of our meetings away from Washington.

I believe our method of electing officers is faulty and undemocratic. The appointing of a nominating committee of three by the president each year, who, in turn, select the president and vice-presidents for the following year, savors a little bit too much of a close corporation. I do not wish to be understood for a moment as intimating that our association has within it a political machine, far from it, and there may never come a time when we are guilty of such methods, yet we are growing, and, in years to come our numbers will be vastly increased. Therefore, to avoid any suspicion of nepotism in the future, $I$ am going to suggest that we employ a different method of electing officers, in order that no available presidential timber, of which there is much in this association, be allowed to lie idle year after year. Whether such a change would take the place of a larger committee, or whether such a committee should be elected by members of the association rather than appointed by the chair, I leave to you to decide, supposing you care to make a change; I am merely advancing my own thought in regard to the matter.

8. The Relation of an Economic Entomologist to his Publications, Lectures, Bulletins, Correspondence, etc.:

The publications emanating from the office of an entomologist represent, undoubtedly, one of the most important features of his work. Consideration of the best time for publishing material, and the nature of the printed matter, the style of illustrations and other factors needed in order to accomplish the most good to those most concerned, should receive our most careful attention. In this connection the economic entomologist stands in rather a peculiar position. $\mathrm{He}$ needs, in the first place, to "make good" if I may use that expression, with his farmer constituents; at the same time his publications reach, or should reach, a class of men and women who call for something a little different in the subject matter than that demanded by the farmer, this class we may designate as the general public. Thirdly: he has 
his reputation to sustain among his fellow entomologists, and at the stations where they are located. Finally, our station entomologist is frequently state entomologist as well, and as such is dependent to some extent upon legislative support, and his publications have to be such as to place his work in a practical and otherwise favorable light before those to whom he looks for financial help.

some years ago we listened to an admirable address by one of our older members, one whom we all respect and admire, in which, while criticising the tendency of some to make a display of themselves in print, he used the expression "beating the entomological drum," thus symbolizing the making of a great noise by an entomologist, and attracting attention thereby, although, as we know, there is nothing in a drum but air, and a superabundance of potential sound. The simile was good; at the same time the spcaker referred to may have taken il too critical attitude toward the matter. As stated above, many entomologists are dependent, more or less, upon popular support. If they do not meet with that, their work, of necessity, stops. What more natural, and really praiseworthy thing than for them to realize that their work has to be thoroughly advertised over their respective states? They probably feel that they have to beat the "entomological drum," although it may not always be to their liking. We are prone, however, some of us, as mentioned elsewhere in this address, to rush into print without sufficient provocation, and it certainly behooves us to adopt some such watchword as "publish in haste and repent at leisure" to prevent many occurrences of vain regret and wounded pride.

I personally regard the illustrations accompanying our publications as also of extreme importance, believing we are all, both entomologists, and the public as well, children of a higher growth, and, as such, are attracted to pictures. I believe, if the farmer's eye is caught by a picture, he is more likely to read the subject matter connected therewith than if his attention were not so attracted. I believe it helps, also, to place, as far as possible, completely descriptive text under each photograph intended to instruct the farmers and general public. In my own work I use illustrations, photos, drawings and colored plates wherever I can, and, feeling as I do, would urge all entomologists, in asking for appropriations for their work, to endeavor to secure a generous amount which can be used for this purpose. Recall, if you please, the accurate and neat illustrations of Slingerland, the finished reports of Felt and others, and you will realize, I believe, how much such productions add to the reputation of the institutions they represent.

As to the comparative merits of photographs and drawings we all 
know there are some subjects which lend themselves only to photography, and of the others the entomologist with a little experience, can readily determine whether a photo or drawing is called for. There are those, but few in number, I believe, who claim the camera should be used in all cases because, as they say "the camera does not lie" and the artist's or entomologist's interpretations are not always the true ones, the personal element being too largely represented. As a matter of fact you can all think of instances innumerable where the camera cannot be depended upon to bring out structural details.

I believe that as a general thing our bulletins, treating of some destructive insect, should contain, first, a brief popular description of the insect and its work, using drawings and photographs generously, and secondly, following the above, remedial and preventive methods. All of this could well be in bold faced type, and should be arranged in a form attractive to the eye. Following this, which represents the essential points, of course, from the farmers' standpoint, may well come the account of the work in detail in ordinarily small type, using whatever illustrations are necessary and available, the more the better, if they are pertinent; the author remembering that fellow workers at other stations may profit by a lucid explanation of methods. Acknowledgment of the source of authorship of illustrations not original should be made under each drawing or photo, not merely referred to in a prefatory note.

Postal card bulletins are, in a way, most excellent, as are a'so bulletins which take the form of spraying calendars. These latter are much appreciated by orchardists, and others who like explicit directions in this line, contisely put. You doubtless all have your vicws upon these points, in many cases far better than those briefly alluded to by the speaker, and we need give no more time to this feature. At the Minnesota Station the entomologist publishes occasional bulletins in the regular station series, also press bulletins as occasion demands, as well as circulars, the latter issued as publications from the office of the state entomologist: The station entomologist, who is also state entomologist, publishes in the lątter capacity, a biennial report to the governor of the state. He and his staff also issue from April to August inclusive a monthly publication known as Minnesota Insect Life, in order to place before Minnesota's farmers, gardeners and others, items of value in suggesting remedial measures at a time when most needed.

The subject of photography is one that has hardly been touched upon by members of this Association in the past. It appears to me that we might well have some co-operative work in this line by those of us who are interested, the aim of such work being dirested toward 
the production of the best forms of illustrations, both photos and drawings, as well as cuts and colored plates.

\section{The Relation of the Economic Entomologist to the Public Press:}

There is no question but that we owe much to our daily and county papers. I know of no better way to get widespread information to the farmers of a certain district quickly, and to be sure of reaching all interested individuals, than by placing such information with the editors of our rural papers, and I have no doubt we all find editors willing and ready to help us in this particular. Personally, however, I have found, and probably my experience has been duplicated many times by those present, that the average reporter loves to make a good story, and he will frequently distort what you have to say to him. personally, in order to have the information make a good showing in his paper. This practice prevails particularly in our city papers. These erroneous statements are copied largely from our daily papers by the county press, and in that way spread over the entire state, and to other states as well. You have probably all experienced the embarrassment of the results of a chance remark made in the hearing of a reporter. I might cite instances innumerable to illustrate this; one in particular occurs to me, coming to my notice recently in my own district.

One of our field men made the remark before a local reporter in the country, that a certain cricket had been observed eating the eggs of grasshoppers. The reporter at once printed the statement that the common black cricket was destroying grasshoppers, which statement not only circulated freely among the papers in various parts of the state, but I was amazed to receive from Kansas a clipping from a Denver, Colorado, newspaper, saying the state entomologist of Minnesota predicted that the black cricket was eating grasshoppers in such numbers that the pest would soon cease to be a cause of anxiety.

Again, too, apart from the errors of city reporters, which are numerous, and sometimes intentional, we find grotesque mistakes in our country papers. The confounding in Minnesota, for instance, of the Seventeen-year Locust, with true locusts or grasshoppers, has been the cause of laughable items in some of the papers. In August a Minnesota county paper came out in a paragraph with startling headlines, with the following declaration: "WITHIN THE PAST WEEK SEVERAL FARMERS HAVE SEEN THE GENUINE RED-LEGGED SEVENTEEN-YEAR OR ROCKY MOUNTAIN LOCUSTS FLYING HIGH IN THE AIR." Again another newspaper referred to "a visitation of the seventeen-year locust." The entomologist, in a desire to straighten out the matter, sent a 
letter, which he deemed fairly lucid, to the editor of the last named paper. In his next issue the editor treated the matter in this way, in big headlines, "No Fear of Grasshoppers. The editor is in receipt of the following letter, which ought to dispose of all predictions and rumors surrounding the pest mentioned." Then follows my letter, which simply referred to the Seventeen-year Locust.

What can we do to make the country papers and our daily press amenable? Personally, I can suggest no remedy, unless it be to give nothing to a reporter unless it is typewritten, and secure from him a promise that if he makes use of the news, it is to be given exactly as stated. Even then, the resulting article is sometimes surprising, to say the least.

The men in my office have been given strict instructicns to give nothing to a reporter over the 'phone. We have tried giving such news repeatedly, only to be frequently embarrassed and dismayed at the result, We, therefore, reply to an inquiry over the 'phone by telling the reporter who calls us up, that we will be very glad to give him information if he will come to the office personally.

\section{The Relation of the Economic Entomologist to his Fellow-Citizen:}

There is a general feeling that a professor must stick to his books and express no opinion upon politics or civic questions of inportance. It is to be hoped that no entomologist, wherever situated, will be content with an interest in his special field of work; society calls upon him to be a good citizen, as well as a good "bugman" and he should feel the responsibility of interesting himself in questions of vital interest, and in the social activities of his community; not only for altruistic reasons, but also because in doing so he rounds out his own character, and avoids the narrowness so often met with in specialists.

Our idea of personal service for the public good might well be enlarged to include our social obligations towards our fellow-rownsmen, and not limited to the somewhat narrow confines of our specialty.

\section{The Relation of the Entomologist to the State Legislature:}

Many institutions forbid their employees to frequent the lobby of the legislature, and almost all would frown upon any member of the staff attempting to get an appropriation for any purpose whatever, which did not have the sanction of the Board of Regents. In our own institution the Board, previous to the meeting of the legislature, prepares a budget for presentation, the result of careful deliberation upon the part of the various faculties and the board. This is as it should be, for we must not forget in our ambition and interest in our 
own work, that the institution must be a unit, and that we frequently have to sacrifice what seems to be our right for the good of all. There are oceasions, however, when an entomologist is privileged, and perhaps, obliged, to fight for a legislative appropriation. This is disagrceable to the highest degree, but seems to be, sometimes, almost a duty, if onc has his work at heart.

\section{1.. The Relation of the Entomologist to Commercial Interests:}

By commercial interests in this connection I refer particularly to those concerned in the manufacture of insecticides or spraying machinery. Manufacturers are quite prone to be overgenerous in donating to entomologists samples of some manufactured article, with a request that it be tested, and a report made upon the results of the test. In our department in Minnesota we avoid absolutely such a relationship, for it is very evident that a favorable report is expected, which will be used later on as an advertisement. Is not this experience practically the same in all stations?

The necessity of avoiding the advertising of anything in our state publications is too evident to be commented upon. In doing this an cntomologist at once opens himself to criticism, as you know. It is sometimes, however, difficult to avoid publicly referring to some article which we have found to be, from our standpoint, the best there is for its advertised purpose. Individuals, of course, have to use their judgment as to what attitude they take in such cases.

Under this caption we might also discuss whether an entomologist is in duty bound to serve professionally all citizens and business interests by giving up a considerable amount of his time to any one party. I refer to requests on the part of business houses for treatment of their store rooms or mills or even private houses which are infested with an insect or insects. It would secm that, should he respond freely and without charge to every firm so calling upon him, he would be so crowded with work of a personal nature, and of benefit to only a few individuals, that his regular legitimate work, which is primarily along agricultural lines, would suffer. Here, again, each entomologist has to decide, from the conditions of his own environment, and the conditions surrounding individual cases, as to the position he takes in this comnection.

\section{The Relation of the Entomologist to the Inspection of Nursery and} Foreign Stock:

Many of us have in our charge the inspection of nurscries, and to this inspection has recently been added the work of inspecting foreign stock imported into our various states. This varies in amount and 
in importance enormously in various localities, and I presume the nurseryman type is about the same wherever we find it, representing a wide-awake, aggressive body of men, as a rule willing to (heerfully abide by the laws, but frequently resenting any legal interference which seriously affects the pocketbook.

Many nurserymen are orchardists, and realizing that the sale of fruit depends largely upon its freedom from insect blemish, are ready to quickly adopt any method for preventing insect injury which the entomologists have found to be good. Of course, among nurserymen, as among all classes of men, we find the narrow minded, the selfish, the short-sighted, and the poorly educated. That we must expect, and fortunate is the entomologist who is tactful enough, and, at the same time, sincere enough to keep up harmonious relations between his office and all of his constituents in this line of work.

Turning to the subject of inspecting foreign stock, different inspectors would naturally have far different experiences to relate. The difficulty we experience in Minnesota is that so many boxes are examined without finding a single trace of injurious insect, that the importers look upon this inspection as needless and absurd, and frequently chafe at the restraint in the matter of unpacking, which is occasioned by our interpretation of the law. The Minnesota state inspection law makes it a misdemeanor to interfere with the state inspector in the discharge of his duties. This prevents the opening of foreign boxes by nurserymen or florists before the arrival of the inspector or his deputy. I speak, however, as a representative of the state where importation is not so great as in many of the states to the south and east of us. I believe that nurserymen generally are in favor of some uniforrn law or laws governing inspection in all states.

\section{Conclusion:}

The time has arrived and passed for closing this address, and mindful of a long series of "don'ts" for public speakers, which I have carefully studied, "Don't exceed your time limit, don't tell a long story, don't try to be funny, don't fatigue you audience, don't wander from your subject, don't apologize, don't be awkward," etc., I hasten to the end, for I fear I have heard for some time a murmur of impatience throughout the audience, in which I could distinguish these words:

\footnotetext{
"And still he talked, And still the wonder grew

That an Entomological President

Should say so little new."
}

Nevertheless the speaker hopes that you have found something of interest and value in the address. Even if you have not, he feels 
that he has done his best, and therefore, makes his bow, retiring with an untroubled conscience, thanking our faithful secretary for his helpful services in connection with the programme of this meeting.

Before stopping, however, I must say a few things which are in my heart to say at this moment. We all join, I know, in the enjoyment of the good-fellowship evidenced on the occasion of these meetings, quite apart from the gain wo experience in information as to new facts. And, after all, it is our attitude toward cach other,- toward our fellowman, that really counts in the long run. Think of many of our present members! Look back into the past also and you will realize how much the personalities we have known meant for us. Let us, therefore, while retaining our high ideals of work and efficiency, entertain is warmth of regard toward each other, which will dull, in a measure, the keen edge of criticism; and let us seek to find the good in our fellowman rather than his weakness. May we not forget that good work, for its own sake, is the best incentive, and further that honesty and generosity are the corner stones underlying altruism. Above all else, remember that courtesy and cultivation, gentleness of minner and refinement of thought are in no way hostile to practical work, and that, although a man may have a high degree, if he has attained that purely by excellence in as special line of work, and has not obtained with it the breadth of culture for which that degres: stands, he fails in reflecting the credit upon the institution granting the degree which he otherwise would.

Many of us were fortunate enough to enjoy, in our carly training, the helpful association with teachers, not only of scholastic ability, but also markedly sympathetic, gifted with a largeness of mind and heart, which made them, and still makes many of them, a power for good amongst their students and in the community in which they reside. These rare and gifted men will not always be with us. Some of them we have already lost, and as time goes on all will have sooner or later, to retire from the field they have so ably filled. Manifestly it is the duty of all, and particularly the younger entomologists, to carry on that enthusiasm for work, that spirit of generous self-sacrifice which made association with their teachers so helpful and delightful. It is for each succeeding generation of entomologists to keep alive and pass on to their successors this holy fire, kindled by our illustrious predecessors.

Vice-President Ball: The constitution provides that the discussion of the President's address shall go over until the next session, so we will go on with the programme and the President will take the chair. 
President F. L. Washburn: I note that the time asked for the members who have papers in no case exceeds fifteen minutes. I will, therefore, hold each member to the time which he requested, and which is stated on the programme.

The first paper is by W. C. O'Kane, on "Methods in Photographing Insects."

\title{
METHODS IN INSECT PHOTOGRAPHY
}

\author{
By W. C. O'Kane
}

The writer of this paper wishes to disavow at the outset any claim to expert knowledge of photography. The matter here presented is not offered in that light.

It is suggested, however, that as a group of workers in a specialized field, we have not brought photography to its highest point of possible service to our particular needs. Insect photography, whether to aid scientific study or for purposes of preparing illustrations, is not the same as pictorial or portrait photography. The questions of posing, lighting and details of process are capable of being answered in a particular way for our special purposes.

The writer believes that we may and should acquire a common fund of individual experiences in photographing insects, and that from these will naturally crystallize out a method of procedure that is the best and that will ultimately be of great value to all of us. This paper is offered, therefore, simply as the writer's individual experience, as a contribution toward the above.

Cameras. In our laboratory three cameras are in general use.

In photographing insects or their work at same size, or at enlargements of two or three diameters, or at similar reductions, an apparatus is used ordinarily cataloged as a "Copying and Enlarging Camera." This is a horizontal stand. The bed is eight feet long. At the front of the camera is a platform which is made to rise and fall by means of a long, continuous thread screw, operated by a hand whecl located at the rear of the stand convenient to the operator when focusing. The lens mounting is provided with a large prism which bends the light rays at a right angle. Thus an object is posed on a horizontal platform, but the operator works always at a convenient level, no matter what the bellows extension may be.

The second camera is used for photomicrographic work at cnlargements of five to eighteen diameters, especially of small, opaque objects, such as flea beetles, and the like. The stand is home made. The bellows and plateholder were once part of a device for making lantern 